\title{
PATRIOTISM, COMPETITIVE NATIONALISM AND MINORITY'S SUCCESSES: ARMENIAN SPORTS IN THE OTTOMAN EMPIRE IN THE PRE-1915 PERIOD'
}

\author{
Hayk Demoyan
}

\section{Introduction}

Sports, along with other national and social activities, became a special driving force for the definition of ethnic identity, especially in multinational states, and served as an important stimulus in the process of formation of nationalism, international competitions, as well as demonstration of superiority of a group. Nowadays, sports play a crucial and decisive role in politics, already reserving for itself a unique place in international relations. International championships, Olympic Games, and especially football World Cups emphasize a specific identity of a nation state, and are an important factor in securing authority and a special status among the other nations.

At the same time, excluding certain episodes from the history of sports, especially the significant role of other nationalities or the bitterness of a loss, sports are also important in the sense of emphasizing one's own advantage. In the multiethnic societies it plays a unique role, becoming an effective factor of the identity formation and representation. This condition is more evident in the case of the history of development of sports life in Ottoman Turkey. In the case of the Ottoman Empire, sports were treated as a form of self-affirmation and national competition in addition to being a means for a healthy lifestyle.

In the late $19^{\text {th }}$ and early $20^{\text {th }}$ centuries, the growing interest in sports, as well as the formation of Armenian sports clubs proved to be significant amongst the Armenian population of the Ottoman Empire. During this time, similar processes began amongst the Armenian population living within the Russian Empire.

In 1908, after the Young Turkish revolution, the short-lived tolerant attitude towards freedom of national minorities and equality of rights was also expressed by awakening a sporty lifestyle. The formation of Greek and Armenian sport clubs and integration of sports into everyday life later on substantially stimulated the formation of similar Turkish clubs and sport unions as well. Thus, in terms of the initiators, sports in the Ottoman Empire were originated and mostly promoted by Greek and Armenian sportsmen and clubs.

Nowadays, Turkish historiography either downplays the crucial role played by national minorities in almost all spheres of the social and economic life. It also concerns the Armenian input in the formation and development of sports in Turkey. The small amount of

1. To cite this article: Hayk Demoyan, "Patriotism, Competitive Nationalism and Minority's Successes: Armenian Sports in the Ottoman Empire in the pre-1915 Period," International Journal of Armenian Genocide Studies 1:1 (2014): 7-37.

The author would like to express his deep gratitude to Vartan Matossian for reviewing this article, as well as for his valuable comments. 
credit attributed to the Armenian community is very incomplete and distorted. The reason for this delicate silence is understandable, as it befits Turkish nationalism and nationalistic historiography, and proves typical to national and memory related politics in Turkey. This denial also encompasses the significant role played by Armenians in Turkish theatre, music, media, book publishing, and several other fields. Turkish historiography finds dangerous any credit given to Armenians for their contributions, and therefore it avoids doing so altogether.

However, in the beginning of the $20^{\text {th }}$ century, the birth and development of Armenian sports in the Ottoman Empire clearly evinced a pan-Armenian undertaking within the borders of the empire, which was confirmed by the idea of creating, as well as officially establishing a united structure responsible for Armenian sport life.

This article is dedicated to a less investigated, but nonetheless very important and intriguing area: the history of the athletic movement and development of sports within the Armenian population in Ottoman Empire viewed in the context of national discourses and competitive nationalisms.

The history of the development of Armenian sport and athletic clubs and unions in the Ottoman Empire begins in the late $19^{\text {th }}$ century, when the first training groups were formed and physical training courses were taught in American colleges established on the Ottoman land. The development of sports activities within the empire was first of all the result of modernization processes, which mostly touched the Armenian and Greek populations and were dictated by specific inter-communal demands, notwithstanding ongoing discrimination and violence against Christian subjects.

The first Armenian sports clubs were formed in the early $20^{\text {th }}$ century in Constantinople and Smyrna. This period was marked by the appearance of professionally educated sportsmen, such as Shavarsh Krisian, Vahan Cheraz, Grigor Hakobian, Mkrtich Mkrtichian, and others who had a considerable role in initiating and developing interest towards sports among Armenians in the Ottoman Empire. The participation of two Armenian sportsmen, Vahram Papazian and Mkrtich Mkrian, in the Fifth International Olympic Games, held in Stockholm in 1912, was a special episode from the chronology of empire's sport life.

The publication of Marmnamarz (1911-1914), the first sport magazine in the Ottoman Empire, created through the efforts of famous sportsman Shavarsh Krisian, became an additional stimulus for creating interest in sports and athletics among Armenian youth residing both in and out of the empire.

The history of Armenian sports in the Ottoman Empire is yet another example of the leading role of Armenians within the empire. It is noteworthy that their national advancement and their tendency to adopt contemporary values definitely strengthened demonstrations of intolerance by Young Turk authorities. The latter tried to oppose by all means the successes of minorities and, to that effect, launched its own mastermind of creation of exclusively Turkish clubs and unions as a branch of the ruling Committee of Union and Progress party (CUP). 


\section{The Development of Sports and Athletics in the Ottoman Empire}

In the late $19^{\text {th }}$ and early $20^{\text {th }}$ centuries the development of capitalism and modernization processes opened new perspectives for the progress and social integration of national minorities in the Ottoman Empire. In this respect, an important role should be ascribed to foreign educational institutions in Constantinople and in other cities of the empire.

Under the tyranny of Abdul Hamid II, it was forbidden for Turkish and foreign youth to establish sports institutions or to go in for sports publicly. In such conditions, sports life was active in American and French educational institutions of the empire, where mainly Armenian, Greek and Jewish young men studied. This circumstance played an important role for national minorities to have more active and developed sport organizations, unlike Turks, who carried this work on an individual basis.

In 1908, after the Young Turk Revolution, the question of urgent development of sports and physical training among the Turkish population became an important part of the internal politics of the CUP. It gained significance as a tool to shape "a new type of Turk," which was to be a healthy generation and, most importantly, to prepare young Turks for military service.

It is known that, shortly after 1908, the leaders of the CUP were consolidating positions of their one-party government, and, at the same time, encouraging demonstrations of Turkish nationalism within the Ottoman society, with special emphasis on intolerance towards national minorities - Armenians, Greeks, etc. An incentive for such political mood was the defeat of the Ottoman Empire during the first Balkan War in 1912. This brought the CUP to the conclusion that the idea of the Ottoman Empire could not save relics of the empire and that it was necessary to create a new type of Turkish society exclusively based on nationalist ideology. The latter became a factor in the evolution of the genocidal character of the CUP politics towards minorities and later on resulted in the large scale genocide carried out against Armenians, Greeks, and Assyrians.

Economic, cultural, and social efforts were all geared to work towards the upbringing of a new nationalistic Turkish generation, and sports and physical training were not out of this goal.

The first exclusively Turkish sport clubs were paramilitary institutions. The members of these organizations were mainly soldiers from military colleges who took part in the Turko-Italian (1911) and Balkan wars (1912-1913). One of these institutions was the "Turk Guçu Cemiyeti," which was founded in the summer of 1913. Its aim was to develop physical education and various kinds of sports among the Turkish youth. "Turk Guçu Cemiyeti" opened its affiliate offices not only in Constantinople, but in other cities of the empire as well. Their activity was mainly aimed at "improving health, regaining physical strength of Turks and growing active generations, persistent against hard times." 2

The history of sports and athletic movement and physical training in the Ottoman Empire is closely connected with Turkish military and Turkish sportsman and CUP member Selim Sirr Tarcan (1874-1957). Selim Tarcan began his pedagogical activities among the Turkish youth in 1909. Having settled in Sweden, he attended physical training courses in the School of Physical Education of Coaches in Stockholm. As far back as the Hamidian period, he would frequently appear in squares and schools in sportswear, in an

2. See Hayk Demoyan, Armenian Sports and Athletics in the Ottoman Empire (Yerevan: AGMI, 2009), 14 (in Armenian). 
attempt to install interest in sports among the Turkish youth. Selim Sirr1 Tarcan succeeded in including physical training in the curriculum of Turkish schools, as well as in madrasah schedules. At first, he was collaborating with Armenian sportsman and editor Shavarsh Krisian, who named Tarcan as "our partner" in one of the issues of the Armenian periodical Marmnamarz. ${ }^{3}$ Later, Selim Sirn Tarcan followed Shavarsh Krisian's example and began publishing a Turkish sports periodical, which, however, did not last long, because Tarcan's undertaking found no reception among the Turkish youth and not many people showed interest in sports.

On the threshold of WWI, another paramilitary sport organization, Osmanli Güç Dernekleri, was created through the efforts of Young Turk nationalists Zia Gökalp and Enver pasha, the Minister of War. It pursued the same goals as the aforementioned organization. Enver invited specialists from abroad, particularly from Germany, to carry out activities aimed at an efficient development of sports and athletics among the Turkish youth. Among those invited was von Hoff, who created the Youth Partnership organization in April 1916, with Selim Sirrı Tarcan as vice-president.

There were 706 affiliate offices of Ottoman Turkish paramilitary organizations established, 351 of which were located in cities and the remaining 355 in provinces. It is worth to note that the leaders of the CUP were actively involved in the formation of Turkish sport clubs, helping their activities, as well as sponsoring the participation of Turkish sportsmen in various international and local competitions and championships. In fact, Enver pasha personally assumed the role of promoter, urging the members of these youth organizations to join the Committee of Union and Progress party. He also became the president of the Turkish scout organization, stressing the importance of the scout movement for training future soldiers and officers.

Among the Armenians of the Ottoman Empire, the practice of sports was also regarded as an important means to be prepared for military service in the Turkish army. In 1911, the Christian subjects of the empire were given the right to serve in the army. The first Armenian graduate-officers had already begun their contribution and did not go unnoticed during the Balkan wars (1911-1913). Armenian sports circles were also aware of this approach, according to which the inspiration of training healthy citizens should serve for preparing one for further military service, rather than to be a self-oriented goal. From this standpoint, Shavarsh Krisian, the editor of the first Armenian sport magazine, Marmnamarz, wrote:

It is necessary to make sport and simple military trainings compulsory in colleges. During military service, the most disturbing problem for a newly recruited soldier is the disciplinary set-up. Other mechanical movements will easily be caught.

It is necessary to form school battalions (Fr. bataillions scolaires) in colleges and prepare future recruits in this way. They have to respond to the recruit with a smile on their face and indirectly cause an increase in the duration of military service. ${ }^{4}$

Though Turkish and Armenian concepts to shape the new generation were somewhere universal, their main approaches and specific undertakings differed greatly. These differences were in direct opposition with each other in some practical ways. The aforementioned fact

3. Hayk Demoyan, Armenian Sports and Athletics in the Ottoman Empire, 16.

4. Marmnamarz, vol. 1, no. 2 (March, 1911). 
becomes more evident when observing different episodes from the development of sport life and athletics both in Constantinople and Armenia, as well as an item published in Marmnamarz.

\section{The Birth of Ottoman Football}

Football appeared in the Ottoman Empire as far back as the late 19th century. The first football match in the empire was played by British residents of Salonika back in 1875 . Some sources indicate that the first football matches were held in Smyrna too. Nevertheless, these games were amateurish and occasional. In the early $20^{\text {th }}$ century, the first professional football players and teams appeared in the empire. In 1901, the Istanbul Football League was created by the efforts of Englishmen James Lafontaine and Horace Armitage. In the following years, Kadikoy, Rumeli, Sunday, and other football leagues were created in the capital of the empire.

The football games in Constantinople were held in the districts of Kadikoy and Moda. As it was forbidden for Muslims to participate in football and similar sport games, the only ones playing at the time were English, Armenians, Greeks and Jews. The first football teams were, as a rule, composed by representatives of different nationalities, including Armenians. Later, ethnically homogeneous football clubs and teams were formed, simultaneously to the development of this sport.

The first Turkish sport clubs, Beşiktaş (1903), Galatasaray (1905) and Fenerbahce (1907), which appeared in the early $20^{\text {th }}$ century, could not run to their full potential during the sultan's reign, and became full-fledged organizations only after the Young Turk revolution in 1908. Afterwards, they became known as football clubs. The main rivals of these Turkish clubs were the Armenian and Greek football teams of Constantinople.

The Young Turk authorities also created a number of clubs and stadiums to organize football matches and other sport competitions. The most famous among them was the Union Club-İttihat Spor stadium, where the Armenian Olympic Games were also held from 19111914.

\section{The Development of Armenian Sports and Athletics in the Ottoman Empire}

Constantinople, the capital of the Ottoman Empire, was the national, cultural, and political metropolis of Ottoman Armenians. National self-governing bodies, various preparatory schools, colleges, and the religious, educational and intellectual potential of Western Armenians were centralized around the Patriarchate. The city also became a center for Armenian sport life.

From the mid of the $19^{\text {th }}$ century, the importance of athletics and physical education was mentioned within Armenian educational circles. For example, the first publication of the Aramian Educational Society, established in 1840, named "Nkaragir Usmants" (by H. M. Gartashiants, Vienna, 1845) had the following mention: "Various schools received directions and I wish that the Aramian Educational Society was also included in the list of those schools, and the college principals could understand that physical growth should contribute to national spirit." 
In late 1853, the Armenian Educational Council recognized the significance of introducing physical education in colleges of Constantinople. ${ }^{5}$ From 1886-1887, the importance of introducing courses of athletics in colleges became an issue. The Education Council mentioned: "The Council regrets that, despite all efforts, it could not provide sport facilities for pupils, because of the lack of trainers. Thus, the Council sufficed itself by entertaining them with different games during breaks."

In the late $19^{\text {th }}$ century, the teaching of physical training was also included in the syllabus of the United Armenian Organization (Cujng upughul nuluknıphılu). Along with the aforementioned discussions, there were publications of translated literature on physical training. This was an uncommon social phenomenon for Ottoman Armenians, and several illustrated books that served as guides for physical training were published in Armenian.

The first one worth mentioning is Dr. Schreber's short book, Physical Training without Instruments. V. Sargisian's translation of this book was published in Constantinople back in 1878. It was followed by the publication of A Brief Physical Training Manual for Schools by Vernel. This book, comprised of 228 pages, was translated by Karen Panosian and published in 1879, once again in Constantinople.

The primary sources have contradictory data about the creation of the first Armenian sports organizations within the Ottoman Empire. According to one of them, ${ }^{6}$ the first football clubs, Armenia and Vaspurakan, were formed in 1900 in Smyrna, and the homonymous teams were created at the same time. In 1901, thanks to the efforts of A. Elmasian, more than a hundred people took part in an athletic show held in Smyrna. During the following years, similar athletic shows were frequent.

As a result of growing interest in physical exercises and sports, the first Armenian athletes appeared on the scene. They were mainly students from foreign, particularly American institutions. There were Armenian sportsmen among the pupils of the American Robert College in Constantinople and the French College in Galatasaray. Students from those schools were mainly interested in Olympic sports such as running, swimming, shot put, disc and javelin.

Several Armenian sportsmen graduated from foreign athletic educational institutions in Europe and later returned to Constantinople. This became a strong encouragement for the development of Armenian sport life, especially team sports and football. Among them were Shavarsh Krisian, Krikor Hakobian, Vahan Cheraz and a few others. Shavarsh Krisian and Grigor Hakobian received their athletic education between 1903 and 1907, following courses in the training school of famous French athlete and coach Edmond Desbonnet. Thanks to these three pioneers and their followers, the athletic movement and sport life received a solid support for further development among Armenians, specifically those in Constantinople.

Shavarsh Krisian's name deserves special mention among Armenian sportsmen. Upon his return to Constantinople in 1909, he set about paving the way for Armenian athletics and sport life, and prompting Armenian youth to take up sports. He initiated the publication of an Armenian sport periodical, with advice from a young intellectual, Hakob Siruni (18901973). The periodical, called Marmnamarz, followed the principles and approaches of the

5. Hayk Demoyan, Armenian Sports and Athletics in the Ottoman Empire, 22-23.

6. Ibid, 36. 
French periodical La Culture Physique.

Other important figures among the followers of Shavarsh Krisian were Grigor Hakobian and Grigor Merjanov. They played an important role in bringing up the youth of Constantinople: Hakobian worked in the district of Uskudar and the villages of Boyaci and Ortakoy, while Grigor Merjanov was active in Samatia and Makrikoy, as well as involved in the formation of the training clubs "Vahagn" and "Titan."

Yeznik Kadjuni became the theoretician of the movement and held lectures on the usefulness of physical education.

Vahan Cheraz, an alumnus from Kedronakan College of Constantinople, became one of the leaders of the Armenian sport movement in Constantinople. During a trip to England, Vahan Cheraz was fascinated by football and, upon his return to Constantinople, started forming Armenian football teams. The second team was called "Santral" (i. e. Central referring to Kedronakan College).

The joint efforts of alumni from Robert and Partizak American Colleges brought about the formation of the "Uskudar" football team in 1906. A year later, Mkrtich Mkrian founded the "Raffi" training club, which operated clandestinely. Later on, another organization called "Hayordiner" was formed in Uskudar.

[In the early $20^{\text {th }}$ century, Armenian students in foreign colleges of Constantinople showed deep love and interest towards physical training and sports. This interest encouraged the promotion of the sport movement.

Some important publications were released in Armenian by 1913, thus helping grow interest towards sports and physical training. Examples of those publications are An L. Kiumlien's “Amenun Marmnamarz" (Athletics for everyone), translated by Eznik Kadjuni, and a booklet called "Boy Scout and the Purpose of his Life," co-authored by Sh. Krisian and H. Hindlian. Other publications such as "Football Book," by Varag Pogharian, "Physical Training," by Arto Galpakchian, and others were released later.

Other foreign institutions, particularly American colleges, had a significant role in the promotion of sports and physical training within Armenian circles beyond Constantinople. Among these institutions were the American colleges of Harput, Aintab, Pardizag and Marsovan.

Armenian sportsmen took part in the international sport competitions organized by Turkish clubs in Constantinople. On April 1-4, 1911 the Turkish "Galatasaray" club organized an international tournament on the occasion of the arrival of a Hungarian sport team to Constantinople. Vahram Papazian, performing in mile run, and Mkrtich Mkrian, alumnus of Robert College competing in discus throw, distinguished them during the competition. Martiros Kuyumcian, who represented the Robert College, became the first winner in hurdling and pole vaulting.

Besides appreciating the Turkish initiative, i. e. the organization of such international competitions, Shavarsh Krisian criticized the flaws in the organization: "To be frank, we warmly welcome the new competition, but it is impossible not to remind our Turkish countrymen that it left the impression of an Oriental ceremony. The result of an inexperienced, not to say careless committee was extreme lack of order."

7. Marmnamarz, vol. I, no. 4 (May 1911). 
Vagharshak Varjapetian and Ashot Papazian had no match in bicycle racing, while Vahan Cheraz and Ararat Krisian were remarkable in swimming competitions organised in Constantinople. Another Armenian sportsman, Vahram Shiranian, alumnus of Hayordiner Union in Constantinople, did not stay unnoticed during tennis competitions and won the Turkish championship several times. Substantial articles published in Marmnamarz bear witness to the success of Armenian sportsmen in international competitions organized in Constantinople.

The activities of Armenian athletic and sport live witnessed the formation of a qualitatively new social field of activity and were a new show of national self-organization that would have a decisive role in providing new features for the formation of new identities and national unity. The birth and rapid development of Armenian sport life in Constantinople encouraged the formation of similar unions and clubs in Armenia and Cilicia. These unions and clubs would later pave the way for the foundation of the Armenian General Athletic Union.

\section{The Birth of Armenian Football}

There are various data concerning the origins of the first Armenian football clubs and teams. It is known that as early as 1905-1906 Shavarsh Krisian formed the first Armenian football team, called "Balta Liman." Both Armenian and foreign sportsmen performed in this team, including Grigor and Levon Hakobian, Shavarsh Krisian, Varag Pogharian, Vardges Aghabekian, Mihran Nakashian, G. Gasparian, S. Poghosian, H. Khupeserian and others. "Balta Liman" took part in international competitions held in Constantinople from 19051906 and achieved a high score victory over the Turkish "Galatasaray," winning the second place. This is actually the first known evidence about a competition where Armenian and Turkish football teams played together.

At that time, Vahan Cheraz graduated from university in England, returned to Constantinople, and brought a ball and knowledge of football. Having introduced the game rules to his classmates of Kedronakan College and future teammates, he created the "Santral" football team. He also fostered the creation of another football team in Proti Island, which included Gabriel Macharian, Tigran Khoian and others. "Skutar," "Kum Kapu," "Tork" and other clubs were formed later.

The club "Tork," formed by the fusion of "Kum Kapu" and "Santral," united Armenian young men of different districts of Constantinople, particularly from Gum Gapu, who were also engaged in swimming, field games, and hiking.

After the proclamation of the Constitution in 1908, "Araks" was one of the best among Armenian football teams. It played successfully with "Tork" against other foreign teams, and took part in the Armenian Olympic Games. The main players of "Araks" were Onnik Frenkian, Garegin Darbinian, Levon Narlian, Hayk Chololian, Hamazasp Panosian, Poghos Nasipian, Tat and Miji Tatian, Petros Savaian, Marut Marutian and others. Furthermore, "Araks" became the winner of the "Rumeli" international league, held in 1911 in Makrikoy.

Before World War I, football teams were formed in nearly all sport clubs of Constantinople, as well as in many provinces.

Armenian football teams participated in league competitions, as well as international competitions organized by some leagues, mainly created in Constantinople. Judging from 
preserved photographs, those football teams had their separate sportswear and signs; the players usually recorded the name of the current team and date on the ball before being photographed.

The development of an athletic movement among the Armenian youth in Constantinople was unprecedented within Ottoman Armenian reality. Other sports were also introduced before the development of football. On the threshold of World War I, about 40 Armenian sport clubs were active, solely in Constantinople.

\section{The Birth of Marmnamarz}

New demands emerged, simultaneously to the growing interest towards athletics and sports among the Armenian population of the Ottoman Empire and the appearance of professional sportsmen. The birth of the first Armenian sports periodical, Marmnamarz, was the result of these requirements. It may be definitely stated that, while foreign missionaries or American colleges active in the Ottoman Empire introduced the athletic movement in Western Armenian reality, the periodical Marmnamarz, published in Constantinople by Shavarsh Krisian (1911-1914), carried out its "Armenisation."

This enterprise was wholeheartedly supported by Hovhannes Hindlian, doctor Garanphilian, Aram Nikoghosian, and Levon Hakobian. Karo Unchian was appointed executive director. The periodical was published with Hakob Siruni's direct participation and support.

Grigor Chololian, a noted sportsman from Constantinople and annalist of Armenian sport history, has fairly stated that Marmnamarz "was a publication based on personal undertaking, efforts and sacrifices." It was the first sport periodical in the empire and a unique phenomenon in the history of Armenian periodical press. It reflected customs and moods of that time, and certainly undertook the important mission of national education and formation, as well as the promotion of its ideological underpinnings.

The first issue of Marmnamarz made a call to Armenian youth in the following terms:

One of our aims is to serve as means and support of Armenian youth to get rid of this existent lifelessness, to unite and start opening clubs in every suburb, village and city, to organize competitions, to foster the development of athletics. All these should be carried out, firstly, in order to be prepared for an austere life, which will prove to be a few of their best years, and, secondly, to demonstrate the noble roots of Armenian blood that has furnished powerful troops. Armenians have not participated in international and local competitions until now, and the reason is neither their feebleness nor the different descent; they were unaware of the existence of similar competitions, and thus they were not ready to get involved..$^{9}$

Since its inception, Marmnamarz tackled various issues: to promote sport life; to instill interest towards athletics and sports, especially in provincial cities and villages inhabited by Armenians; to keep the public informed about ongoing sport events within and without the Ottoman Empire, as well as to coordinate the activities of Armenian sport clubs and the organization of championships.

8. Azdak, December 17, 1938.

9. Marmnamarz, vol. I, no. I (February 1911). 
Naturally, Marmnamarz provided much space for Armenian and foreign authors who focused on athletics, healthcare, teaching, and development of sports. It is noteworthy that the promotion of sports and athletics was not just an end in itself, but was conditioned by concern about bringing up healthy generations, especially in Armenian schools.

The organization of the Armenian Olympic Games was possible through the mediation of Marmnamarz, a fact that proves the considerable role played by the periodical.

In his article "The voice of youth," Armenian sportsman Vahram Papazian, who represented the Ottoman Empire in the Stockholm International Olympic Games in 1912, commended the activity demonstrated by Greek sport organizations and the attention they devoted to athletics, but at the same time reproached the idleness and other useless morals and manners of Armenian youth:

Be sure that if a single Armenian athletic club were opened in Constantinople, shortly thereafter Armenians would achieve a leading role among all similar clubs in the Ottoman Empire."

We already have sportsmen who can compete with the glorious Greek Thorizas and emulate his achievements. Europe did not recognize the Armenian descent, so let it recognize our strength. ${ }^{10}$

Marmnamarz also carried out activities directed to the creation of athletic and sport clubs. Moreover, while sport was viewed as an indicator of civil awareness, the creation of sport clubs and especially the development of team sports were considered important tocreate a newly-shaped national character, a new philosophy for vitality and success, following ideas expressed by Shavarsh Krisian:

The creation and development of sport clubs are very important especially for us, Armenians, since sports will unite us. One of the most criticized aspects of Armenian character is the instinct of individualism. It is always difficult for Armenians to obey others in community life. The spirit of individualism should be diminished by the help of these clubs and love towards community life should be spread among Armenian youth...

In brief, sport clubs are furnaces where not only physical strength, but also organized unity and civic education are forged. ${ }^{11}$

Active correspondence was maintained with Marmnamarz from Smyrna, Kutahya, Arabkir, Partizak, Caesarea, and other cities and villages. Sport amateurs and sportsmen from the Armenian communities in Egypt, Bulgaria and even the United States were also actively involved. Dispatching periodical issues to provincial schools and colleges was another important issue; the promotion of periodicals among Armenians outside Constantinople was carried out through donation of issues to locals.

The athletic movement that was gaining full speed brought forth the idea of creation of united sport structures. This idea was also led and backed by Shavarsh Krisian. In particular, the existence of several Armenian football teams in Istanbul and Smyrna inspired the idea of a separate football league, but the invitations sent to the football clubs of Constantinople did not have the expected result.

10. Marmnamarz, vol. 1, no. 2 (March 1911).

11. Marmnamarz, vol. 2, no. 18 (September 1912). 
The first issues of Marmnamarz were published as illustrated journals, while the following issues were introduced as Daily Newspaper on National Physical Revival, and later on as Daily Newspaper on National Physical Education. In this way, Marmnamarz emphasized its real mission and became the most important tool for promoting sports within the Armenian young men of the Ottoman Empire.

In 1911, during the first year of its publication, Marmnamarz was published as a monthly journal and had 10 issues. The next year, it became a semi-monthly to fulfill the request of its readers and published 24 issues. The frequent change in the addresses of publishing houses and editorial offices was a hint that the newspaper confronted financial difficulties.

The publication of Marmnamarz was a unique phenomenon, as Tigran Khoian, a noted Armenian sportsman and scout leader, remarked in his memoirs: "Marmnamarz filled in a considerable gap and appeared just on time to help introduce the importance of physical education and assist those who were resisting the past efforts in this field. It became an advisor and a guide for Armenian youth..."12

Marmnamarz was published until 1914. Its founder, Shavarsh Krisian, was a victim of the Armenian Genocide. After World War I, Hay Scout, a different periodical substituted Marmnamarz. Besides dealing with issues of athletics and sport, Hay Scout was also the official newspaper of the Armenian General Athletic Union.

\section{Sport and Athletics in Smyrna}

As it was mentioned above, the first football games were held in Smyrna. Armenian football player Zareh Kuyumjian was among sportsmen and players of the town. Arthur Elmasian, after thorough studies of athletics in France, returned to Smyrna and began work as a coach in the Armenian National College. In 1900 Elmasian managed to purchase sport facilities and other accessories to create a gym in the yard of the Mesropian College. In June 1901 Elmasian organized an annual sports show, involving more than a hundred people. The shows became periodical and they were clandestinely. However, in 1905 Elmasian was denounced and had to leave Smyrna. After Elmasian's departure, his associates continued the work of their coach and formed the Mesropian Union.

During the harsh years of the reign of Sultan Abdul Hamid II, Armenian sportsmen had no opportunity to perform in international competitions and sought to perform in foreign teams. For this reason, most Armenian sportsmen performed in the Greek team "Pelops." The majority of local Armenian sportsmen were interested in football and the consequence of this interest was the creation of "Football Union," the first Armenian football team in Smyrna.

Over time Armenian sportsmen created the sport clubs "Qnar," "Vaspurakan," and "Sahakian." The union of these four separate teams marked the creation of the "Armenian Hunters' Club." The latter had its own regulation, but gave the above-mentioned four organizations a free rein to act independently. Thanks to the zealous efforts of Armenian sportsman Mkrtich Yangian, this newly-formed club reached 600 members, and had about 1000 active members in late 1912. In 1910 the four Armenian teams held matches to choose

12. See Hayk Demoyan, Armenian Sports and Athletics in the Ottoman Empire, 51. 
the best Armenian football teams that would compete for the International Cup Tournament of Smyrna.

The football team of the "Armenian Hunters" Club" achieved great success during 1911-1912. The Armenian team successively competed with the Greek teams "Pelops," "Apollon," and "Panionios", and the English "Burnabad," and obtained glorious victories. In March 1912 the Armenian team won the Silver Cup of Smyrna. This achievement became a source of inspiration for Armenians, especially in Smyrna. Grigor Chololian noted in reference to the positive effect of the victory:

This honorable victory was a strong moral, rather than material success for the union.

It served as an encouragement to create a wholesome movement within the Armenian community. All skeptic and indifferent people supporting the organization felt the expressive spirit of the race. ${ }^{13}$

For obvious reasons, the sport and athletic movement of Smyrna stopped during World War I and gained new momentum afterwards.

\section{The Development of Sports and Athletics in Western Armenia and Cilicia}

Constantinople and Smyrna were the main centers of Armenian sport life within the empire. At the same time, the importance of the development of sports and athletics in the Armenian populated provinces of the empire came into agenda. Besides officially introducing physical training in its syllabus, the Educational Board of Constantinople started training sportsmen for provincial cities and villages through the joint efforts of Shavarsh Krisian and Aram Nikoghosian.

Erzerum, with the Armenian Sanasarian College, certainly had a leading role among the athletic movements in the province. As Grigor Chololian attested, this important center of Armenia "became an educational centre for art and literature in the depth of dark Anatolia." Swimming and skating were put on strong basis in the colleges, which also had sport syllabi. Surviving photographs that captured the demonstrative performances of Sanasarian College students confirm its high level of athletic physical training. Another fact that supports the abovementioned statement is the special mention of athletics in diplomas issued for Sanasarian college graduates.

From this perspective it is noteworthy to mention Shavarsh Krisian's opinion published in the Armenian newspaper "Harach" of Erzerum:

Athletic exercises will become a blessing for Armenians and will spread from Constantinople to Armenia. We should not spare anything for the propagation of these exercises. On the contrary, the youth sport clubs should be a part of our daily interests and should become our daily bread. The athletic courses should be held continuously for the improvement of the race or, as people would say, for the "national" standpoint. It is necessary to straighten spines through physical exercises in order to have healthy thought and soul. ${ }^{14}$

13. Azdak, March 1, 1939.

14. See Azdak, December 29, 1938. 
The Armenian Olympic Committee, referring to the idea of making the Armenian Olympic Games as an all-Armenian event and the need to include Armenian sportsmen from other regions of the empire, mentioned the following in its call:

The Olympic subcommittee has always considered only the small part of the Armenian population, yet never the Armenians of Constantinople as a whole. Thus, it should always give preference to regional projects. After considering the existent facilities of Constantinople, the subcommittee has to establish the first gym in Constantinople, train athletic coaches there, and send them to the provinces. ${ }^{15}$

The Armenian Revolutionary Federation (ARF) showed particular zeal to organize sport and athletic clubs in many regions of the Ottoman Empire. After the Young Turk Revolution, ARF clubs were operating both in and out of Constantinople. Some of these clubs were the ARF Sport Club of Adabazar, the "Aramazd" sport union, and the "Atlas" and "Kaytsak" clubs in Nikomedia and Samsun respectively.

Similar sport clubs were also formed in Zeitun, Van, Divrik, and Hachin. Football, shooting, fencing, boxing, and other sports were widely popular in these clubs.

Among the organizations operating in the Ottoman Empire before the Armenian Genocide were the Young Christian Organization in Van, the United Club in Hachin, the Explorer's Union in Mersin, the Armenian Explorer's Sport Union in Aintab, and the "Masyats" sport union in Konia. The latter was directed by Mikayel Bartikian. Military and physical trainings were also obligatory in the Jenanian College of Konia. The college periodical wrote the following:

Alongside with moral and cognitive growth, physical training of pupils is under good care. Each pupil should follow the important course of athletics. Besides, each pupil is permitted to use sport facilities during holidays. ${ }^{16}$

"Vahagn", another Armenian sport club, was established in Van. Yeghishe Qadjuni, one of the founders of the "Torq" club, left for Van to propagate the movement there and shortly after his departure the alumni of colleges in Van organized a sport show, Swedish exercising and a rewarding ceremony. The local "Vaspurakan" football team was also created with the efforts of Qadjuni.

Deep interest towards sport tournaments and athletics was shown in Sebastia (Sivas). The "Partev" club was established here by the initiative of fourteen members in 1911. This club was the leader of the athletic movement among Armenian population of Sebastia and in a due course the number of its members grew. The "Varazdatian" club and the "Artsiv" union also functioned in Sebastia. In late 1911 the first field tournaments were held in the city and the "Zavarian" club was established in the village Kovtun. A football team was created in the town of Niksar, located in the province of Sebastia.

The fast development of athletics in Constantinople had an impact on the athletic movement of Partizak (modern Bahçecik). On June 2, 1911 the first field show and football matches with participation of Armenian sportsmen were held in Partizak. The "Artsiv" sport union was also functioning actively in Partizak, while Mateos Zarifian (better known

15. Marmnamarz, vol. 1, no. 9 (October 1911).

16. Ikonion, Jenanian College, Konia, vol. I, no. 7-8, July-August, 1912. 
as a prematurely died poet) from the Partizak Senior College achieved a brilliant success in athletics.

Field tournaments and athletic games became widely spread in American and Armenian colleges of the province. Separate alumni clubs of the Anatolia College were created in Marsovan. These clubs merged in 1908 and formed the "Shavarshian" union. Along with football, the union also had a baseball team and a periodical called "Ayg." Besides the Anatolia College, active work was being carried out in the St. Sahakian College. Annual sport competitions were periodically organized by the "Hayordi" student's union of that college.

Four college teams of Harpoot, i. e. American "Euphrates" College, French, German colleges and the National Kedronakan College, performed in the first football matches that took place on May 20, 1911. These colleges also housed basketball matches and bicycle races.

The first sport show at the college took place on June 16, 1912 by the initiative of the alumni of National Central College, under the presidency and guidance of archimandrite Artavazd and Coach Hakob Serikian. The coach bestowed "beautiful medals" upon the winners.

According to the information found in Marmnamarz, at the same time the trustees of St. Karapet Monastery of Efkere, located in the Caesarea district, "appreciated the useful role of sport and kindly provided sportsmen a beautiful spacious field," where sport games were held.

The "Artsiv" and "Gayl" sport clubs were formed in Vezir Kyopru and Ç enkiler. The "Ariuts" club was established in the Sahak-Mesropian College of Sivri Hissar.

In 1911 an Armenian Youth Union was formed in Yerznka (now Erzincan), followed by the establishment of the "Zhayr" sport club (1912). The latter was aimed at "revealing and developing the physical abilities of club members." Later on, the sport club "Artsvi" was reorganized in Trebizond and became known as "Sharzhum." A rare photograph showing sportsmen of the "Artsiv" club, published in the December 1912 issue of Marmnamarz, has been preserved.. The fate of the members of the club is unknown.

In one of his articles, Shavarsh Krisian mentioned that:

...Sport clubs, especially, should be formed in Armenian districts. For this purpose it is important to create networks and interconnect districts with distant small, minor cities and villages. For example, a network in Van, Erzerum, Sivas, etc., where all [cities and villages] should be linked to their centers. We should consider local conditions to organize sport games according to these networks, as well as instructions received from centers a few months before the start of Armenian General Olympic Games. The centers should allocated means to send the sportsmen who have achieved the best results in these contests to Constantinople or to the city that has been determined as capital of the current year. Of course, the rest of the amount should be disbursed by the committee. ${ }^{17}$

The excerpt shows that the pioneers of the Armenian athletic movement, besides

17. Marmnamarz, vol. 2, no. 7 (August 1912). 
their wishes, had a definite action plan, a visible strategy, and a policy for achieving their goals.

The Armenian athletic and sport movement was also spread to Aleppo and Beirut. In 1914 athletics was introduced to Armenian colleges of Aleppo for the first time through the efforts of coach Karapet Hovakimian, who had arrived from Harpoot. The "Aghbyur Marmnamarzakan" athletic club established in the Nersesian College in Aleppo also housed a library and a gymnasium. There were several field exhibitions at the college, organized by the club. In Beirut, Armenian sportsmen mostly represented local American educational institutions.

The "Artsiv" club functioned in Samsoun and had a great impact over the local Armenian population, especially youngsters. In his memoirs, Vahan Minakhorian, a prominent Armenian political figure, refers to the interest that the Armenian youth had towards athletics, as well as to the organised field exhibitions in Samsoun. ${ }^{18}$ It is noteworthy that local Turkish authorities also applied to Armenian coaches and asked them to organize similar events within the Turkish population.

Armenian athletic and sport unions and clubs were established in Rodosto, Ordu, Izmit and in the Armenian college of Amasia. The "Vishap" and "Ararat" sport clubs started functioning in Ovac1k and Manisa respectively.

Besides Constantinople, the sport life also progressed in Armenian populated Cilicia. Armenian clubs from Iskenderun and Adana participated in field exhibitions periodically organized in this region. Most active were the "Sisvan," "Hetum," "Levon" and "Ruben" football teams from the Armenian Central College of Dortyol and a number of pupils from Cilician orphanages, whose number had grown after the terrible Armenian massacres in the spring of 1909. The local Armenian population realized the importance of developing self-defense abilities among the population. Such trends were particularly evident in Chorq-Marzpan, known for its heroic selfdefensive struggle during the massacres, and in other neighboring cities. Other coaches were invited from Constantinople to Adana to develop athletic sport life among the local youth. Varag Pogharian and Mateos Zarifian played an important role in the organization of the athletic movement in Cilicia.

The organization of the Cilician Olympic Games deserves a special mention. They were held on April 1914, in a special venue north from Chorq-Marzpan. Sport clubs from Adana and Alexandretta took part in this exceptional event. Thousands of visitors, including about forty Turkish officers, attended the competitions. A football match took place between the "Sisvan" team from Central College and the multiethnic team of Alexandretta. It was followed by running and long jump competitions between teams of Alexandretta, Adana, Chork-Marzpan and the Kelekian orphanage. The alumni of the Central College performed Swedish exercises that made a great impression upon local spectators. The participants were awarded special medals bearing the inscription "Cilician Olympic Games, 1914, ChorqMarzpan." 19

These events promoted the creation of new unions and clubs.

18. See photos in Hayk Demoyan, Armenian sports and athletics in the Ottoman Empire, 83.

19. Marmnamarz, vol. 4, no. 2 ( June 1914). 


\section{Armenian Women and Athletics}

The growing interest towards athletics and sports was mainly noticed among men. Nevertheless, Armenian women did not stay indifferent. It was surely difficult for women to get engaged in athletics within a Muslim society. After the proclamation of the Ottoman Constitution in 1908, Armenian women and girls were allowed to engage in the sports athletic movement. At first, women were not involved in separate competitions, but performed in field shows and in Armenian Olympic Games. They took part in solemn ceremonies, such as the opening of competitions and the awarding ceremony.

Marmnamarz and its editor Shavarsh Krisian were instrumental to install interest towards sports among Armenian women in Constantinople. In the articles published by Krisian and others, healthy life was considered as a guarantee for bringing up a healthy generation. For this reason, the inclusion of women in sports life took special importance. Special articles were devoted to the need of introducing athletic courses in women's colleges. In regard to this, Krisian mentioned the following:

If we consider a woman getting a physical education, we should realize that even in boy's colleges athletics is still viewed as a precious activity and this course could not be used more "efficiently" than by turning it into a limited reading lesson. I am sharing my personal experience. Children may have the opportunity to run, jump and cry, but at least in colleges they perform a disgraceful act, because among us a playful and lively child is considered disgraceful and an obeying, calm boy is considered a good child. The first is subject to punishment, while the second shows a sign of good conduct. Nevertheless, this disgrace is somehow forbidden to girls, it is shameful for girls to run and jump like children. Those girls who cannot conceal their natural instincts would be called tomboys...

Schools that took every step to prevent the slowly spreading perversion unconsciously furthered it, and we ascribe this phenomenon to schools that not performed their role.

Every ruthless person would try to take his/her revenge, but we shall hope that Armenian women will not revenge on their children for their mistakes and even wrongs, on generations, shortly, on their nation. ${ }^{20}$

Another article published by Marmnamarz was more expressive. The author compared and criticized the customs and morals of Armenian women, as well as the adoption of European customs, while the need to get involved in sports was neglected. Pointing out that the involvement in sports and physical education was a precondition for bringing up a healthy generation, the editor of Marmnamarz stated:

Women's liberation movement is taking a meaningless direction among us. Sometimes it is expressed by generous and useless luxury. It tries to come forth during fleeting conversations, expressing through deceptive masks of sophism, argument, and female perception. We are not concerned with this, but with the demand of saving the race. Well, we shall be educated, speak, argue, sing or play, but what should be done to secure the health of Armenian race? The best, strong, and brave offspring depends on our future mothers. Some would like to resemble Western women and would carefully imitate them, but why wouldn't they imitate

20. Marmnamarz, vol. 1, no. 1 (February 1911). 
the affection that those women have towards not only the women's movement, but also their health and physical strength? ${ }^{21}$

During the early 1910s the first women sport clubs were established with the efforts of Armenian sportsmen. For example, Shavarsh Krisian formed the "Yesaian Alumni Union" in Constantinople. It was the first women's sports athletic club in Western Armenian society. In 1912 the second sport club for women, called "Izhi" ("Health"), was established in the Scutari district of Constantinople by the initiative of a few women. In 1913 the alumna of Nikoghosian College established the "Yerand" athletic club for women, which soon had more than 60 members. By that time, the "Zavarian" women's union, using Swedish training technique, was formed in Sivri Hissar. In 1913 Armenian sportswomen took part, for the first time, in the Second Armenian Olympic Games.

The teachers of the Yesaian College in Constantinople were trained to introduce physical training among Armenian girls and pupils in provinces. They were sent to Dortyol, Hachin, and other cities inhabited by Armenians as teachers. Athletic courses were also introduced in women's provincial colleges. Although conservative views and lifestyle were dominant within the Armenian population, thanks to Marmnamarz the propagation of athletic concepts among Armenian girls and women created serious prerequisites for bringing up a healthy generation. This movement managed to overcome resistance from conservative circles and called to bring a new kind of involvement into the Armenian athletic and sport movement.

The participation of Armenian girls in the scout movement greatly expanded women's inclusion in the athletic movement, especially during the post-war period. Besides the existence of health issues, this active involvement was also dictated by the necessity of national rebirth after the Armenian Genocide.

\section{Armenian Olympic Games (1911-1914)}

The 1908 revolution gave new hopes to Ottoman Armenians in terms of security and respect of basic human rights. It was also viewed as a new opening for liberalism in social life and activities in different realms, including the development of sport life.

Shavarsh Krisian and his followers brought forward the idea of organizing Armenian Olympic Games in 1910 with the aim of bringing together Armenian sport clubs and unions for intercommunity competition. Various Armenian sport clubs were much inspired and encouraged by this idea. Vahram Papazian published similar ideas in Marmnamarz.

Four all-Armenian Olympic Games were held during 1911-1914 and were resumed in the post-war period after a short interruption. These games were unique in Ottoman Armenian social life.

Participating Armenian sport and athletic clubs and groups which were taking part in those games set a number of records. Winners were awarded with medals, cups, and other prizes.

Grigor Chololian presented the prehistory of the idea to organize the Armenian Olympic Games.

21. Marmnamarz, vol. 1, no. 7 (April 1 1912). 
Hardly had "Marmnamarz" been published, when it became a favorite Armenian periodical. It was necessary to start a unique project to inflame this spark of inspiration. One day we were sitting in a restaurant, as usual, when the conversation turned to the Stockholm Olympic Games. Suddenly we came with the idea of creating the Armenian Olympic Games. ${ }^{22}$

A preparatory meeting was held with representatives from Armenian sport clubs and unions of Constantinople, by invitation of the editorial staff of Marmnamarz. The organizational committee was composed by Aram Galenter, Gevorg Terjimanian, Yeghishe Qadjuni, Levon Hakobian, Shavarsh Krisian, Martiros Kuyumchian and Hovhannes Savaian.

The first Armenian Olympic Games were held on May 1, 1911 in the stadium of the "Union club" of Constantinople, with nearly all local sport organizations participating: "Aharonian" club from Beşiktaş, "Tork" club from Kum-Kapu, "Asparez", "Arax" and Armenian Revolutionary Federation's (ARF) club from Pera, "Joghovurd" circle from Samatia, "People's Club" from Kadikoy, "Armenian Club" and "Masiats" club, "Kukunian" circle from Topkapu, Armenian Youth Union from Pera, Armenian coeducational union from Şişli, the Armenian alumni of American "Robert" College, "Raffi" union, the editorial staff of Marmnamarz, "Artavazd” sport club from Guruçeşme, Progressive Union of Scutari, and Student's Self-development Union.

Almost 2000 people attended this unprecedented event. Further the games were held on June 3, 1912, June 16, 1913, and in the summer of 1914. The latter did not last long because of the beginning of World War I.

Shavarsh Krisian, referring to the idea of Armenian Olympic Games, mentioned:

Armenian Olympics should stop uniting just sport institutions of Constantinople; this fact will only limit its value. Instead, people should encourage the games and thus make them a well-organized event. Armenian Olympic Games should be an allArmenian event that would gather all Armenian population of Turkish Armenia. It should become a gathering place of Armenians from Caucasus and from other centers densely inhabited by Armenians. It should resemble the ancient Greek Olympics. For this purpose it is necessary that the provincial population get involved, be trained and organized. When a connection between different unions gathered for a single purpose is established and financial means are available, all athletic and sport clubs will form a single union. This union will necessarily keep in touch with all other similar organizations, located in centers densely inhabited by Armenians. Thus, Armenian Olympics would become an all-Armenian event, the national means for expressing harmonious power, and would thus prove its value. ${ }^{23}$

It was envisaged that sportsmen from Armenian Hunters' Club of Smyrna would also take part in these games. However, they could not arrive in Constantinople because of the quarantine imposed in the city.

According to the written statement, the following competitions were held: 100 yard dash (for adults and children), quarter-mile run, half-mile run and one-mile run competitions,

22. Azdak, January 3, 1939.

23. Marmnamarz, vol. 2, no. 8 (April 1912). 
cross-country race, sack racing, and flag racing. Preliminary records were set in shot put and discus throw. The games also included high jump, long jump, pole vault, tug of war, and two-mile bicycle racing.

Competitions were marked by the participation of Sargis Mkrian and Martiros Guyumchian from "Robert College," Vahram Papazian from "Artavazd" club and Varag Pogharian from "Tork" club. Winners and runners-up were awarded golden and silver medals, respectively.

The first Olympic Games, despite organizational gaps, opened a new page within the history of Armenian sport history and athletic movement. Constantinople- based athletic clubs and the ones in provinces were greatly inspired by this event, which was a prerequisite for developing the idea of the Armenian General Athletic Union.

The second Armenian Olympic Games, held on June 3, 1912, were more organized in comparison. These competitions were also organized in the stadium of the "Union club." New records were set during the games, again with participation of most Armenian sport clubs from Constantinople.

The following sports were included: 100 yard dash, half mile run, quarter-mile run, cross-country race, flag racing, standing long jump, pole vault, long jump, high jump, discus and javelin throw, shot put, and two-miles bicycle racing. By suggestion of noted sportsman Grigor Merjanov, various human pyramids were formed.

The third Armenian Olympic Games were held on June 16, 1913 under the patronage of the Armenian Patriarch of Constantinople, Zaven Ter-Yeghiaian, and were presided over by famous Armenian musician Komitas. The latter also led the award ceremony during the final part of the games and "did not forget to kiss the winners' foreheads."

Armenian scouts and girl-scouts participated in the third Olympic Games, maintaining order during the competition alongside with acting officers.

The patronage of the Patriarch was criticized in the Ottoman Armenian conservative press. Shavarsh Krisian, however, raised his objection:

The current state of affairs in the world is as follows: when a nation has the sympathies of others, its people will try to discover the past and present state of affairs, general intellectual, moral and physical traits of that nation. Armenians were in a similar condition. Effective physical trainings were the result of the adopted Western values and even the most commendable movements that started within narrow circles could not be noticed and considered national. For this reason we wished to have the presence of the Patriarch and at the same time give national features to the movement that has started. In this case, Europeans could say "this is how Armenians resemble us. ${ }^{24}$

The participation of two Armenian scout groups in the Olympic Games, representing the Hindlian College and the suburb of Scutari, was a novelty. The Armenian spectators were greatly impressed by the proud military march of scouts, accompanied by music.

The third Armenian Olympic Games were enriched with with the arrival of representatives from sport clubs of Smyrna, Adabazar, Partizak and Caesarea. The representative from Armenian Hunters' Club of Smyrna, Gevorg Habetian, had an outstanding performance. He won the competitions in 100 meter run and long jump. Sargis Tarigian from Adabazar also had a successful performance.

24. Marmnamarz, vol. 3, no. 6 (June 1913). 
The other novelty during these competitions was the introduction of a new metric system of registering the records and scores. This was an officially approved method used during the International Olympic Games. The following sports were included: 100 meter, 400 meter, 800 meter sprints and 1500 meter run, flag racing, standing long jump, high jump, long jump, shot put, javelin throw and 5000 meters bicycle racing.

The fourth and last Armenian Olympic Games were held on June 14, 1914, just a couple of weeks before the beginning of World War I. The games were opened with the flight of doves that reiterated an ancient Armenian custom coming from the Navasard (New Year) games.

The fourth Olympic Games hosted 13 sport clubs and 81 Armenian sportsmen from different cities of the empire. These clubs were mainly from Constantinople: "Armenian sport club," "Hayordi," "Perperian," "Tork," "Arax," "Artavazd," "Nor Dprots," "Vahagn," "Euphrates," "Nor Uzh," "Sasoun" and "Andranik." There were also sportsmen from Smyrna, Adabazar and Marsovan.

The participation of the "Knar" orchestra, accompanied by V. Srvandztiants and Barsegh Kanachian, aroused great excitement among the Armenian spectators.

The Armenian Olympic Games had great importance for the further development of Armenian athletic movement and sports, as well as for the creation of a joint body, which would coordinate the movement.

\section{Armenian Sportsmen at the 1912 Stockholm International Olympic Games}

Armenian sources, particularly the author of "Marmnamarzin girqy" (The book of sportsman), Alexan Mkrtichian, referred to Habet Papazian as an Armenian gymnast who took part in Olympic Games unofficially held in Athens (1906). Mkrtichian also mentioned that "...Armenians were the first among the Eastern nations to participate in Olympic Games..."25

According to Turkish sources, the Ottoman Olympic Association was established on July 20, 1907 and registered by International Olympic Committee in 1911. The first participant representing the Ottoman Empire in the International Olympic Games was Hungarian Aleko Mulash. However, there are no grounds for asserting that his participation in the International Olympic Games of 1908 was the first official record on the participant from the Ottoman Empire.

As a matter of fact, for the first time in the history of Turkish sports two Armenian sportsmen, Vahram Papazian and Mkrtich Mkrian, had a unique chance of representing the Ottoman Empire in International Olympic Games.

Along with the idea of organizing Armenian Olympic Games, the idea of sending Armenian sportsmen to participate in the International Olympic Games was discussed within sport circles and in the pages of Marmnamarz. This discussion was derived from the need of "upholding the honor of Armenians."

25. Hayk Demoyan, Armenian Sports and Athletics in the Ottoman Empire, 113. 
Turkish athletic clubs also made some attempts to send representatives from Ottoman Turkey to participate in this worldwide Olympic competition. Referring to this question, Turkish sportsman Selim S11ri Tarcan writes:

...we decided to take part in the 1912 International Olympic Games to be held in Stockholm. Through Ikdam and Sabah newspapers I invited young inexperienced people who wanted to take part in various competitions and to obtain a license. At the same time I sent a written request to the Ministry of War and the Ministry of Navy to provide the names of those officers who wanted to participate in international competitions. At that time, the government did not properly estimate the political and social role of these international competitions. As a response to my request, the government did not consider the competitions important from military perspective and thus gave no adequate answer to my request. I did not receive answer from other formed unions, except for the one or two football clubs that were operating in Istanbul... ${ }^{26}$

The question of sending Armenian sportsmen to the 1912 Stockholm Olympic Games was a widely discussed topic in the early 1912 issues of Marmnamarz. As the participation in Olympic Games was quite a difficult and costly task, the "Artavazd" sport union organised an all-Armenian fundraising to cover the costs and send Vahram Papazian to Stockholm.

This idea was backed by Marmnamarz:

This is a great idea and we think that it is quite unnecessary to attempt to raise the strong sense of civilization during Olympic Games. We think that a desire to take part in Olympic Games means to understand one of the secrets and reasons of the majesty of being a great nation. Resembling to such nations means to have lofty ideals on civility and it is just for this reason that we think that this ideal is promising for the future of Armenian people.

If we admonish our children and brothers to meet with people who are both intellectually and morally superior to them, why don't we all do the same thing with superior and more enlightened nations?

It is secondary for us whether Papazian will take the first or the last place. The important thing is to participate as an Armenian.

Let Papazian take even the last place, but be presented as an Armenian; it is important that the name of Armenia be recalled at the competition, involving participants from great nations. It is true that for about 30 years Europeans have known Armenians as a robbed, killed and ravished, wailed and bloodstained nation. Many people pitied and then forgot us and now it is high time that our name reappears on their tongues.

We want that the civilized world know us through our work and efforts. ${ }^{27}$

Provincial Armenian clubs were involved in fundraising activities too. The "Partev" sports club from Sivas granted an Ottoman half-gold for that purpose. V. Papazian and M. Mkrian arrived in Sweden thanks to these fundraisings and the personal contributions of Ottoman Armenians.

26. See Şevki M. Çapan, Türk Sporunda Selim Siiri Tarcan (Muğla: Ünyay Yayinlari, 1999).

27. Marmnamarz, vol. 2, no. 2 (January 1912). 
While arriving in Stockholm, Armenian sportsmen noticed that the flag of the Ottoman Empire was not flying among the flags of participating countries. They complained to both Olympic organization committee and the embassy of Ottoman Turkey. They both demanded that the flag of the Ottoman Empire be displayed among the flags of other countries or else they would refuse to take part in the competition.

Papazian provided interesting details in his memoirs:

When in the morning I got to Stockholm, I noticed that the streets and important institutions were adorned with flags of all big and small countries participating in Olympic Games, but there was not a single Turkish flag among them.

I was much concerned with this fact. After all, I was officially representing Turkey and this uncomely attitude assumed towards my country was a kind of reproach for me.

I took a car and went straight to the Turkish embassy to express my anger and demand immediate action, with the suitcases in my hand, not even having entered the flat provided to me.

After introducing myself and receiving congratulations on the part of Ambassador, I said: "Bey Effendi, the air of Stockholm is depressing for me and I would like to return to my country... The entire Stockholm is adorned with foreign flags, except the Turkish flags, and this fact is a kind of reproach for me and against my country. I'll stay here only if measures are taken and the flag of my country waves beside all other flags.

The Turkish ambassador was petrified in front of me...Like many others, he couldn't believe that an Armenian might have such strong love and respect for the Turkish country...In that moment, he was probably not realizing one clear fact: Armenians have always loved their Turkish country and it was the Turks, who did not love their exemplary Ottoman Armenian population and were always chasing after them in every opportunity... ${ }^{28}$

Vahram Papazian continued his story: "Two hours later the Turkish flag was actually flying in every corner thanks to a young Armenian, who after a few years was to wail upon the millions of unburied corps of patriotic Armenians ... all of them massacred by Turks." 29

The Olympic Committee put Ottoman flags in the streets and in the main stadium of Stockholm. Thus, for the first time in the history of the Olympic Games, the flag of the Ottoman Empire was raised thanks to Armenian sportsmen. Further, the Armenian sportsmen found out that, as a reaction to endless violence, committed by Ottoman Turkish government, the Swedish had refused to raise the Turkish flag among others flags of participating countries. It is noteworthy that the representative of Turkish Olympic Committee, Selim S11ri Tarcan, was not present during the opening ceremony to take part in the procession with Armenian sportsmen, although he was in Stockholm and had agreed to get in touch with the delegation.

2541 sportsmen from 28 countries took part in the Stockholm International Olympic Games. Besides Ottoman Empire, representatives from Egypt, Luxemburg, Portugal, Serbia, and Japan took part in the competitions for the first time.

28. V. Papazian, Love, love and love (Beirut: Sevan, 1962), 53. (in Armenian)

29. Ibid. 
Vahram Papazian participated in 1500 meters run competition, displaying the Ottoman state symbol on his shirt. It is interesting that the suggestion of sewing the flag of Ottoman Empire was made to the wife of the Ottoman to Sweden.

Mkrtich Mkrian achieved great results in pentathlon and discus throw and took the fifth place. Vahram Papazian was near the finish and was leading during the 1500 meters run competition. Unfortunately, he fell to the ground several meters before crossing the finishing line and lost the winning place.

The Swedish mass media referred to the participation of Armenians in the Olympic Games. The local "Stadium" newspaper hosted Mkrtich Mkrian in its office and interviewed him:

Mr. Mkrtich Mkrian is one of the few Ottomans participating in the Olympic Games.

Mkrian, accompanied by the Secretary of the Ottoman consulate in Stockholm, a sportsman, visited our editorial office yesterday. Mr. Mkrian is 19 years old. He is a student of Robert College and an alumnus of this year. Mkrian is going to participate in decathlon and pentathlon, discus throw with right and left hands, iron and javelin throw. Last year he was a winner in competitions held in Athens. He has also strong skills in wrestling. ${ }^{30}$

Although the two Armenian sportsmen did not obtain any prize, their participation in such an important international competition was widely discussed inArmenian and Turkish circles.

This is how Vahram Papazian commented about his participation in the Stockholm Olympic Games:

In 1912 the International Olympic Games were to be held in Stockholm. Turkey was also invited to participate. Nevertheless, Turks had no sportsmen to send, unlike Armenians. Thus, they decided to send an Armenian sportsman to represent the huge Ottoman Empire and succeeded. For the first time in history, Turkey was taking part in such international competition as a nation, thanks to two Armenians, as it will be seen later.

These two Armenian sportsmen brought honor and were useful to their country. A few years later, a Turkish wrestler dishonored the Turkish people in the same country and was deported from Sweden for having stolen a watch. ${ }^{31}$

During the next years, the question of sending Armenian representatives to Olympic Games was hotly discussed. It was considered not only an important step to promote sports life among Armenians, but also became a matter of national expression of the suppressed group before the international audience.

Thanks to Vahram Papazian and Mkrtich Mkrian, Armenian sportsmen participated for the first time in the modern International Olympic Games, opening a new page in the history of Ottoman, as well as Armenian sports.

An article by Shavarsh Krisian in Marmnamarz referred to the participation of the two Armenians:

When Turkey, an empire with ample means, could not send a single sportsman, two

Armenians had the honor of representing the Ottoman Empire again. We are glad

30. Alexan Mkrtichian, Book of Athlete (Constantinople: Arev Press, 1926), 50 (in Armenian).

31. V. Papazian, Love, love and love, 45. 
indeed and we hope that more Armenians will participate in the sixth International Olympic Games to be held in 1916, in Berlin. ${ }^{32}$

Although the participation of two Armenians in the international event was remarkable, no Turkish circle give importance or praised the Armenian community's efforts to represent the Empire in such an important gathering. This showed not only the negative attitude towards non-controlled self-expression of Armenians in the world, but also disclosed an initial negative and nationalistic setting among Turkish political and intellectual circles.

\section{Sports and Nationalist Competition}

Along with the promotion and development of sports and athletics, Turkish nationalism was becoming more intense in all the fields of social activity. The purpose of this intensifying nationalism was to fight against national minorities and to oust them from their leading positions in the areas of economy, culture, and education. In other words, the main purpose of the policy adopted by Young Turk leaders was to ensure the domination of Turkish element in the social and economic realm of the Ottoman Empire.

The conflicts during the simultaneous development of Armenian and Turkish sports should be viewed in the context of post-1908 revolution developments, which enabled some sort of temporary liberalism for minorities, while putting the parallel discourse of both communities in development strategies.

The participation of Armenian sportsmen in the Stockholm International Olympic games of summer 1912 was widely discussed both in the Armenian and Ottoman Turkish press, but from different viewpoints, shaping the importance of such participation or non-participation for national identity. In this respect, the efforts by Turkish sportsman and founder of Ottoman Olympic Committee Selim Suri Tarcan to send a Turkish sportsman to Stockholm failed, and they triggered an interesting evaluation of this fact in his writings. Tarcan viewed sport competition as completion in the military field, where the representatives of participating countries had to demonstrate superiority to their competitors. Tarcan referred to the parade performed by sportsmen from participant nations and to the presence of national flags in the field with evident disappointment:

Each chosen representative of the 26 countries was there, except us. This pain filled my eyes filled with tears. The huge Ottoman Empire that had once given to the Europeans the phrase "as valiant as a Turk" today is not taking part in this strong competition. This is a very painful setback. Naturally, I applied to the government in order to send a few Turkish sportsmen to this important event, since we have been accustomed for years to expect everything implemented by the government. However, I could not share my concern with anybody. The answer from the Ministry of War made me even more grievous. As an answer to my both private and official request, Fuat pasha, the advisor to the Ministry of War, replied: "The issue is not of military importance. Thus, it is not necessary to send policemen to this event." How can one not be despaired by similar answer? Nevertheless, the Olympic Games were firstly important from the military perspective. It is enough to say that there were one general and 6 policemen

32. Marmnamarz, vol. 2, no. 12 (June 1912). 
from Germany, 1 commander and 5 policemen from France, 1 general and 30 policemen from Russia, while Italy, Belgium, Denmark, Greece and Serbia have sent more policemen with different titles. For the nations, which think that future war will not differ from sport competition, it is not difficult to understand the real essence of Olympic Games. ${ }^{33}$

Those lines were written just a couple of months before the First Balkan war and the overall rhetoric of the Turkish sportsman is quite understandable. Shavarsh Krisian, the editor of Marmnamarz, responded to the abovementioned statement. The article, entitled "Our answer," actually touched the topic of national competitiveness in sports, projecting broader nationalist competition in post-revolution Ottoman Empire. In his reply article, he put:

We've attentively read the above-stated article by Selim Sirr1 Bey several times. There's no need to state that we present this article to the readers only for the opinions and viewpoints it contains.

The absence of Turkish policemen during Olympic Games has never upset us. Conversely, we feel offended that Selim S11rı Bey puts every effort to differ between a Christian Ottoman and Turkish Ottoman, if he ever admits that Christians are Ottomans.

Let's not forget that this article is published in a Turkish newspaper and is addressed to the Turkish public. Therefore, Selim S11r Bey shows himself in his true colors before Armenian and particularly Turkish public. This means he doesn't contemplate that his article would be read by non-Turkish public. For this purpose, there is no need to keep bringing about the outdated formulae, which have lost their faded meanings long ago.

Let's cut the long story short. Two Armenians travel to Stockholm by their own means and fundraisings, introduce themselves not as Armenians, but as Ottomans, wear uniforms with the Ottoman Crescent depicted on them, struggle to introduce Ottomanism among different teams and in Europe, and win applauses from the public as Ottoman sportsmen. And, at the end, Selim S11rı Bey falsifies and distorts the facts by saying he could not find Turks participating in Stockholm Olympic, without ever mentioning two Ottomans who happened to be Armenians.

Isn't this enough to reveal the psychology that unfortunately dominates in the mindset of, as it is considered, the most progressive elements of this country?

Either this country is for Turks only and we Armenians and other nationalities are not citizens of the Empire, because we are not Muslims, or this country is called the Ottoman Empire, where every individual and every nationality have equal responsibility and rights...

Today, when the Ottoman Empire, which is not a country for Turks only, as Selim S11rı Bey thinks, wages a struggle for existence, Armenians should also take arms and protect their Ottoman country.... ${ }^{34}$

The development of sport life and organized competitions contributed to some extent to divergences in the Ottoman urban society and resulted in problems of political importance.

33. Translated from Ottoman Turkish to Armenian by Shavarsh Krisian, see Marmnamarz, vol. 2, no. 18 (September 1912).

34. Marmnamarz, vol. 2, no. 20 (October 1912). 
The Armenian argument about sport competitiveness also bore nationalistic character. Namely, a victory of Armenian sportsmen over Turkish, Greek, and other clubs was presented as a natural phenomenon, thus prioritizing Armenian sportsmen and the significance of records set by them.

Thus, after the victory of the Armenian Hunters' Club's football team over the local Greek "Pelops" team in Smyrna, the Armenian comment on this success was:

Today we thank Smyrna Armenians and wish that they have supporters wherever they are, and from now on we are sure that Armenian youth, who forms the basis of the Armenian race, will have victories in sports as well, like in anything else. From that time onwards, Armenians will have a different way of life and condition, will receive different treatment from foreigners, and will consequently have another future. ${ }^{35}$

The match between the Armenian "Balta Liman" and the Turkish "Galatasaray" teams held in 1906 is of particular interest. About 3000 Armenians, Europeans, Greeks, and Turkish people attended the match. Armenian football player Stepan Khanjian, who participated in the abovementioned game, recalled that among the guests there were also Turkish high-ranking officers who "were invited by Galatasaray to applaud their victory..." The match finished with an appalling victory of the Armenian team that scored five unanswered goals.

On September 2, 1912 an international tournament organized by the "Fenerbahce" club was held in the "Union" club stadium in Kadikoy, Istanbul. Armenian, Turkish and Greek clubs and sportsmen participated. The tournament was attended by various layers of Turkish population and especially servicemen. Taking advantage from the Bayram holiday, they "hastened to come and encourage the participants. The Turkish guests thought that they would win the match and show the outcome of four-year efforts."

Then Marmnamarz added:

All expectations of Turkish sportsmen died off, because in nearly all competitions Armenians preserved their leading positions and performed under the applauses of guests and especially Armenian visitors...

As one can judge from the aforementioned results, Armenians were chief leaders in the competitions. It is true that the records, compared to the ones set during the Olympic Games, were not that good, but clearly showed how much Turks fell behind in sport competitions. They need to train in order to take good positions in competitions organized by them. ${ }^{36}$

Another interesting extract found in the pages of Marmnamarz shows the reaction of Turks after Armenian victories. It is even more interesting to view this paragraph in the context of different opinions and even clashing views concerning pan-Ottoman ideology:

When Armenian visitors began applauding their compatriots, Turks grieved and objected, asking why they were discriminating between them, since they were all Ottomans, etc. There were many discussions that made us reflect why Turks exploit

35. Marmnamarz, vol. 2, no. 17 (April 1912).

36. Marmnamarz, vol. 2, no. 18 (September 1912). 
the advantages of Armenians and consider their traits and rights as Ottoman, but during massacres and riots they have counted us as Armenians and not Ottomans. Therefore, we are asking this question to them. ${ }^{37}$

Some Armenian clubs started to recruit Turkish members in order not to be accused of having only Armenian members and falling under the danger of being closed.

The formation of scout organizations with its semi-militaristic character among Armenian youth brought new impetus in the conflicting discourse, creating harsh and negative counter steps on behalf of the Young Turkey. The semi-military character of scout detachments and scout gatherings and marches of Armenian groups in the Ottoman capital city may have troubled Young Turkish authorities. The parallel creation of similar structures among Turkish youth became strongly connected with the army and started to broaden its network under the aegis of War Minister Enver pasha, who headed Ottoman Turkish scout organizations.

On April 1916, Enver pasha made a special proclamation for youth organizations, where he referred to the situation in the country, as well as to the importance of social education and the realization of national desires. This was evidence that ethnic minorities in the Ottoman Empire were already being considered an alien element and therefore it was intolerable to see them as successful competitors in the field of sport. One of the clear evidences of exclusion of Christian minorities from the social strata of the Ottoman Empire was the solid support provided by the CUP to Turkish sport clubs and scout organizations with an aim to counteract the successes of minorities in the field of sportive competitions.

Young Turks paid special attention to the creation of Turkish sport clubs and in some cases they sponsored such initiatives directly. In late 1913 Celal Bayar, the Executive Secretary of Young Turkish party, visited Smyrna and allocated funds to form Turkish athletic club.

The Turkish "Altay" club was established on June 6, 1914. The fellows of this club were members of the "Union and Progress" party. It was not accidental that Dr. Nazim Bey, who was one of the Young Turkish ultra-nationalistic figures and one of the main perpetrators of the Armenian Genocide, headed the "Fenerbahce" sport club in 1916.

\section{The Armenian Sport life and Genocide}

The policy of genocide implemented by the Committee Union and Progress shortly after the First World War broke out resulted in a huge blow on the social, political and cultural life of Ottoman Armenians. Hundreds of Armenian intellectuals, among them also sportsmen, became victims of the genocidal policy. In 1915 nearly all Armenian sport clubs and unions in the Ottoman Empire ceased their existence. One of the victims of the genocide was also the editor-in-chief of "Marmnamarz," Shavarsh Krisian, who was exiled to Ayaş with a group of Istanbul Armenian intellectuals and shortly afterwards killed.

The cruel retaliation against eminent Ottoman Armenian intellectuals committed by the CUP government was conditioned by their violent intolerance to the leading positions of

37. Ibid. 
national minorities. They aimed to create a new Turkish nationalistic ideology based on the leading motto "Turkey for Turks."

Among the victims of Genocide was Galust Arkhaian, from the Gedig Pasha subbranch of the "Artavazd" sport club, who was exiled to Deir el Zor and died there. Another Armenian sportsman, Vardevar Yapuchian, also died during the exile to Deir el Zor. Hayk Chololian, a sportsman from Constantinople and a football player in the "Arax" team, joined the Turkish army and served as an assistant to civil engineer in Sivas. He was among 1700 Armenian soldiers and officers killed during the general murder of Armenian servicemen of the Turkish army.

Among the victims of WWI and the Armenian Genocide were Yervand Nshanian and Gevorg Kerestechian, the founders of the "Sasoun" athletic union in Makrikoy, Constantinople; Hovhannes Gorian, one of the best football players of "Robert" College; Ghazaros Guyumchian, alumnus of the "Sanasarian" Armenian college of Erzerum and a coach in the college of Uchpek village, located near Chemeshgezak; Gevorg Terjimanian, one of the organisers of the First Armenian Olympic Games; Poghos Zenneian, representative of the scout movement, and many others. Among the victims of the Armenian Genocide was sportsman Avetis Aychian, member of the "Torq" athletic union in Constantinople. He was in Bitlis working as a teacher in a Turkish college when he was deported and killed.

The majority of Armenian sportsmen who were members of clubs outside Constantinople and Smyrna were deported and killed.

Nothing is known of the fate of the Trabzon based "Artsiv" (Eagle) club of Armenian sportsmen, whose picture was printed in one of the 1912 issues of "Marmnamarz."

The April 1920 issue of the periodical "Hay Scout" had an inscription on its cover that recalled the great loss: "In memory of martyred and killed sportsmen."

\section{Conclusion}

The establishment and development of Armenian sports, scout clubs and unions in the Ottoman cities and villages inhabited by Armenians heralded a new shift in vital intercommunal relations among Western Armenians. The creation of sport clubs and the introduction of athletics in schools and colleges were regarded as significant means for preserving Armenian identity and promoting the idea of a new generation. The latter was to attain a leading role in the improvement and reorganization of national life.

The creation of the Armenian General Athletic Union was not just a mere idea and was not limited to the context of only athletic issues. It was set to realize and support the idea of uniting Armenians and training a healthy generation out of orphanages.

The animated athletic and sport life in the Ottoman Empire could not remain unnoticed to Ottoman reactionary and nationalist circles; the success of Armenian sportsmen and the development of Armenian sport life were against the officially pursued policy to consider the Turkish nation above everything.

The newly-formed Armenian sport movement incurred serious demages because of the premeditated plan of implementation of Armenian Genocide. During 1914-1915 all Armenian sport clubs were closed, several Armenian sportsmen were exiled and massacred. 
However, shortly after WWI the movement showed signs of rebirth. This rebirth marked another bright page in the chronology of Armenian sports and athletic history.

The scout movement served as an additional stimulus to spread the athletic athletic movement, as well as to speak for the demand of bringing up a healthy generation. This policy was especially expressed by athletic initiatives in Armenian orphanages.

After the defeat of the Ottoman Empire in WWI, the collapse of the empire brought a general recession, which also affected the sport field. However, sports and sports competitions would soon become one of the key elements of intensification of Turkish nationalism; after the declaration of the Turkish Republic, the new nationalist authorities attributed great value to sport and physical training, and considered it a significant means for claiming a new ideology and bolstering the supremacy of the Turkish nation. 


\section{BIBLIOGRAPHY}

1. AGAU and April 24, Dedicated to 90th Anniversary of Armenian Genocide, Published on April 24, 2005 (Antelias, Lebanon: AGAU Central Administrative Board, 2005).

2. Bakhtikian Nerses, Abp., "Armenian General Athletic Union in the Near East," in Marzik, third issue, XXVII year (2008).

3. Bakhtikian Nerses, Memorial Book of AGAU, 1918-1958 (Beirut: AGAU press, 1958), (in Armenian).

4. Çapan Şevki M., Türk Sporunda Selim Suri Tarcan (Muğla: Ünyay Yayınları, 1999) (in Turkish).

5. Demoyan Hayk, Armenian Sports and Athletics in the Ottoman Empire (Yerevan: AGMI, 2009), (in Armenian).

6. Hindlian H. T. , True Pages (1890-1912) (Constantinople: H. Mathevosian press, 1913), (in Armenian).

7. Houlihan Barrie, "Sport, National Identity and Public Policy," Nations and Nationalism, 3(1) (1997).

8. Khoian Tigran, Immortals of the Martyred Nation (Beirut: Altha press, 1983), (in Armenian).

9. Krisian Sh. and Hindlian H. , The Boy Scout and the Purpose of His Life (Constantinople: G. Paghtatlian press, 1913), (in Armenian).

10. Kumlien L., Athletics for Everyone (Constantinople: Manuk H. Gochunian press, 1912), (in Armenian).

11. Minakhorian Vahan, Disastrous Days of 1915 (Venice, St. Lazarus: Mechitarists prees, 1949), (in Armenian).

12. Mkrtichian Alexan, Book of Athlete (Constantinople: Arev Press, 1926), (in Armenian).

13. Muratian Varuzhan, "The Foundation of AGAU," Marzik, 1-2 (4) (1984).

14. Okay Cüneyd, "Sport and Nation Building: Athletics and Sport in the Ottoman State and the Committee of Union and Progress, 1908-18," The International Journal of the History and Sports 20:1 (2003).

15. Pahri Zaruhi H., "Armenian Woman and Scoutism," Hay Kin, I, (November, 1919).

16. Polley M., Moving the Goalposts. A History of Sports and Society Since 1945 (London: Routledge, 1998).

17. Papazian V., Love, love and love (Beirut: Sevan, 1962), (in Armenian).

18. Siruni Hakob, Autobiographical Notes (Yerevan: Sargis Khachents press, 2006), (in Armenian).

19. Teodik, Yearbook for Everyone, XVI year (Constantinople: M. Hovakimian press, 1922), (in Armenian).

20. Teodik Arshakuhi, "Girl-Scouts," Hay Kin 1, 3 (December, 1919), (in Armenian).

21. Torbörn Sundquist och Ian Wiséhn, Olympiska tecken. Minnen från Olympiska spleen i Stockholm 1912 och 1956 (Stockholm: Kungl. Myntkabinetten, 2004), (in Swedish). 
22. Torikian Byuzand, History of Armenian General Athletic Union until 1939, vol. I, (Beirut, 1995), (in Armenian).

23. Ulker Erol, "Contextualising 'Turkification': Nation-Building in the Late Ottoman Empire, 1908-1918," Nations and Nationalism, 11:4, 2005.

24. Vernel, Brief History of Athletics in Schools (Constantinople, 1879), (in Armenian).

25. Yeghiaian Byuzand, Armenian History of Adana, (Antelias, Lebanon: Press of the Armenian Catholicosate of Cilicia, 1970), (in Armenian).

26. Yurdadon Ergun, "A Brief Evaluation of Development of Turkish Sport from 1839 to 1923.” http://www.thesportjournal.org/article/sport-turkey-post-islamic-republicanperiod

\section{Periodicals}

26. Azdak, Beirut, 1938-1939.

26. Marzik, Beirut, 2008-2009.

26. Marmnamarz, I-IV years, 1911-1914.

\section{Archive Collections}

27. Grigor Chololian collection, AGMI archive.

28. AGBU Beirut Central Administrative Board archive. 